\title{
Career in the narratives of early adolescents
}

KEYWORDS

Career, professional plans, middle school students, early adolescents, identity

\begin{abstract}
IIn the paper "Career in the narratives of early adolescents" I set out to describe the selected aspects of constructing an identity during adolescence in the context of prospective professional development among young individuals, who seek to define their future selves. The paper also outlines the social and cultural context of constructing a career, which should potentially be addressed by young individuals long before they enter the labour market. The paper also describes the selected findings of my own concerning career narratives constructed by early adolescents, descriptions of selected career aspects provided by middle school students, and their personal predictions and plans on their prospective life as professionals.
\end{abstract}

\section{Towards a professional career, or adolescents constructing their identities}

Adolescence brings a diverse period in one's life, and it eludes simple descriptions, especially in the world faced with continuous social change.

However, by analysing individual development and socialisation, it is possible to describe the quintessential aspects of this life period, which may apply to most of the young people, their individual differences notwithstanding.

With professional career in mind I would like to focus in this paper on those aspects of adolescent development and socialisation that are most applicable to describing the process of growing up with a view to entering the labour market and finding a position in it in accordance with the realities of the marketplace.

Adolescence is inextricably linked with a specialised type of social participation. As they strive to establish their social standing, adolescents tend to occupy transitory or temporary positions in social structure. The functional aspect of their participation can be seen in the way individuals take up activities that are expected 
to secure a relatively stable allocation in a stratified structure. The psychosocial aspect in turn entails the necessity to gain knowledge required in a given culture and shaping mental dispositions that organise a personality, identity, or habitus (see Modrzewski, 2004). In the course of their education teenagers discover their resources and capabilities by practising a variety of social roles; as part of preparatory tasks (initial choices, projects, or plans) they learn how to perform the roles of adults and take on adult responsibilities, which to a large extent are linked to developing a professional career.

Donald Super's Life-Span, Life-Space Theory of Career Development, which was further developed and extended by Mark Savickas, attributes much importance to both psychosocial and sociocultural factors in constructing educational and professional plans and developing a professional career. Much focus is also put on combining various social roles, including professional ones, across the life-span. The theory propounds (Super D. M., Savickas, Super C.M., 1996) that the professional development process occurs in the context of personal development and identity strengthening, which results from an interaction involving individual psychophysical potential, experience in education, and social training provided to teach a variety of social roles. The process of experimenting with one's career unravels as a compromise, as it were, between self-concept and reality. The conditions for the compromise are negotiated in the process of learning and adopting various roles that are both imaginary and real. Social conditions, cultural reality, and labour market reality serve as a context for constructing individual careers, which are determined by personal, psychological, and biological factors.

In his classical concept Donald Super describes professional development as a series of five periods attributed to particular life and career development stages. These stages include: growth in childhood (age: 4-14), exploration in adolescence (ca.14-24), establishment in early adulthood (25-44), maintenance in adulthood, and decline in late adulthood. No matter how flexible the approach to the time line of each of the stages, the tenets of the theory seem to be well suited for the purpose, notwithstanding post-modern social chaos, the unpredictable labour market, and an increasingly non-linear nature of contemporary professional careers. Admittedly, Super's career development cycle provides a general model rather than a reflection of individual biographical trajectories. Similarly, it is not exactly suited to shifting post-modern reality. That said, it remains applicable (Guichard, Huteau, 2005).

According to Super (Super, 1990; Smart, Peterson, 1997), throughout adolescence young individuals are focused on exploring professional domains, shaping interests and life preferences, and choosing professions for potential consideration 
in order to eventually select a more or less concrete professional domain and different variants of their educational journey that would help them to reach it.

The transition from childhood to adulthood entails a normative identity crisis vs role confusion (Erikson, 1968, 1989), which binds an individual's family cycle with their school and professional life cycle, thereby creating a favourable environment for adopting a variety of different social roles. Exploring the question who am I? is inextricably linked to the question who am I going to be in the future?

James Marcia argues that adolescent individuals, on the one hand, explore reality by defining their values and selecting life goals (while going through a crisis, they experience various measures intended to shape these values and goals); and on the other, they take on commitments by choosing ideas and life domains and constructing their life plans. The combination of the two, that is, exploration and commitment, results in different identity statuses. An identity achievement can be seen in individuals who explore reality while taking on commitments that are typical of adulthood; an identity moratorium involves exploratory activity without taking on commitments; an identity foreclosure is characteristic of individuals who have given up exploration while taking on commitments that were imposed upon them; an identity diffusion is in turn typical of people who refrain from activity and refuse to take commitments (Marcia et al., 1993).

Some of these identity statuses, which all emerge as a combination of exploratory activity and accepted or refused social commitment, may not always be conducive to taking on adult commitment and a timely and smooth transition from school to the labour market.

The adolescent identity crisis overlaps with an external pressure imposed by the absolute necessity to make subsequent decisions as part of the schooling process, which more often than not influence an individual's functioning in the labour market and derive from the sequential nature of education at each and every stage of the schooling process.

Individuals seek criteria and explore the boundaries of a coherent and stable identity that is focused on a uniform set of values. "... The stake of adolescence is not only about integrating ego domains or properties that emerge at particular stages of childhood. They should be part of a larger framework created by society, so that they may organise themselves in a uniform manner..." (Guichard, Huteau, 2005, p.144). ${ }^{1}$ Besides family, which plays a major role in childhood, it is now school that proves to be key for the secondary socialisation process while serving as an area to explore education- and job-oriented opportunities and build

\footnotetext{
1 Translation provided by the English translator based on the Polish version of the book.
} 
a prospective career capital. This area is also one of the most powerful carriers of the market-oriented narrative.

Individuals "anticipate themselves" (Erikson, 1968, 1989) by making choices, taking decisions, constructing plans, and either making them a reality or abandoning them or procrastinating.

The longitudinal study of my own demonstrates that young people resort to a variety of strategies to plan their future career prospects. These strategies in turn reflect their current identity status, ${ }^{2}$ including the identity's personal, social, and biographical variance. These strategies include: condensation ("narrowing down choice"), which most probably reflects an identity achievement; addition ("laying down blocks"), which is hypothesised to represent an identity moratorium; stochastic ("random choice" or "following others"), which is expressive of an identity diffusion; actualist strategies (termporisation, as in "when the time is right", and passivity, as in "there's no future for me"), which are probably related to an identity moratorium or identity diffusion; and a play-safe strategy ("a bird in the hand is worth two in the bush"), which is somewhere in between an identity achievement and identity moratorium (Piorunek, 2004, 2007, 2011; cf considerations on future planning styles in Piorunek, 2017).

Bernadette Dumora (Dumora, 1990; Guichard, Huteau, 2005), who carried out a research on middle school students( aged 11-16), in turn demonstrates that this particular developmental stage (which partially overlaps with Exploration in Super's Theory) coincides in time with three types of operations young people have to perform. Primarily, young people pursue "comparative reflections": they put together the elements that describe their selves and professions of their choice, think about particular jobs by establishing tautological links between themselves and a person performing a given job, and perform more elaborate projections at subsequent stages using abstract categories through classification or logical implication. Secondarily, young people proceed to "probabilistic reflections": they perform a subjective assessment of their capabilities and the likelihood of success, which is mainly defined through their current academic achievement. This results in developing a variety of life scripts, which are not only based on rational premises, but are also exposed to emotional pressures that emerge as young people explore reality and seek identity. Early adolescence culminates with "implicative reflections": they combine particular means (self-assessment of academic capabilities) with particular professional ends, which produces either a consonance or

\footnotetext{
2 The combination of selected future planning strategies, which were defined in the course of empirical verification, with particular identity statuses is merely hypothetical, and no separate study has been completed on the subject.
} 
dissonance that emerge as conclusions from comparative and probabilistic considerations.

Linda Gottfredson points out that individuals create a cognitive map of professions that reflects the following stages as they develop from childhood onwards: focus on size and strength, focus on gender-related tasks, focus on social perceptions related to the status and prestige of a given profession, and focus on self, individual interests, talents, and values, which emerges in adolescence (ca. 14 years of age). As they draw the line between the professions they would either accept or refuse based of the above-mentioned criteria, adolescent individuals tend to define the area of acceptable professional prospects. As they continue to explore, adolescents may find it necessary to compromise their preferred professional aspirations with the perceived and self-assessed availability of these aspirations (Gottfredson, 1996, Guichard, Huteau 2005).

Listed by different authors, all these operations and strategies that adolescents use to make their academic and professional choices and construct their career development plans require that they take into consideration the cultural and social macro-context, which helps to clarify these processes in the existing reality.

\section{Cultural pressures of career construction}

The age of discontinuity (Druckner, 2008), which is marked by the permanent discontinuity of structures and social processes, is best described by change in almost every life aspect. The labour market is also exposed to change, its blurred and chaotic reality creating new conditions for adolescents to develop their identities and construct their professional careers. With the globalisation and transculturalisation of the economy, it is now more widespread that individuals pursue their careers outside of their country, traditional professions, or professional activity areas. The diversity of transition journeys and processes from school to the job market in turn provides opportunities to build personalised professional biographies in which the variety of challenges and non-standard perspectives both serves as a chance and poses a threat to building a stable professional identity in an extended time perspective. The discontinuity of existence, which is best reflected in individuals frequently changing their professional profiles, jobs, workplaces, domiciles, and cultural environments, forces individuals to make their identities more flexible, both temporally and environmentally (Bańka, 2011).

The development trajectory from the past to an anticipated future derives from the cognitive awareness of the life course, which is clarified by events, peo- 
ple, and institutions, all of them sharing one distinctive trait, that is, discontinuity. Giddens's identity dilemmas are particularly brought to bear in contemporary reality. The activity aimed at preserving a coherent identity narrative requires perceptual and behavioural involvement that at the same time unifies and dissects social experience, while navigating between helplessness and control over the life course, authority and insecurity in an independent and solitary construction of a life journey, and personal experience and the marketable experience of the consumerist lifestyle (Giddens, 2007).

A job, which may temporarily be lost or changed multiple times, is not the only category that organises individual identity, whereas the absence of continuity in the organisational framework of professional functioning makes it more difficult to position oneself in the job market and consolidate a professional role. The safe rules of the relational contract that are considered stable and predictable (long-term job agreements) are now increasingly replaced by a short-term transactional contract, which is intended to provide for a formal exchange of resources and services. Contemporary young generations make their professional decisions in permanent uncertainty, ambiguity, unpredictability, and absence of control and professional agency. Contemporary young generations are quintessentially different from previous generations in that they grow up with constant access to modern technologies, function in both actual and virtual realities, and are more focused on the present time perspective. Presentists are characterised by multiple identities (real and virtual), diffused involvement in many areas, and an augmented time profile; they are confused and lost in the amount of data which they cannot arrange in order. This leads to a decreasing sense of self-agency and control over reality and a decline in biographical narratives that make the prospective behaviours and goals meaningful and desirable (Kubacka-Jasiecka, Passowicz, 2014). Generations $\mathrm{Y}$ and $\mathrm{Z}$, the terms used more frequently in the media rather than by social studies (cf Wrzesień, 2007; Kubacka-Jasiecka, Passowicz, 2014), are focused on maximising job-related profits and making them more immediate while making a journey across the free market a more personalised one. This in turn makes their identities more fluid. The formation of Self in a transcultural and relatively unstable environment makes it necessary for young people to continuously redefine their identity status. This in turn means that the questions about the nature and shape of identity can hardly fit in the temporal boundaries of traditionally defined adolescence. Such questions are going to recur in subsequent stages across the life-span.

While 1960s-born cohorts considered academic achievement a predictor of professional success, those born in the 1980s and 1990s more often quoted predictors such as social class or nepotism. At the same time, the inflation of academic 
credentials and over-training were often used to describe changes occurring in education and the marketplace (cf Boudon, 2008; Szafraniec, 2011; Długosz, 2013; Bańka, 2016). Individuals born after 1995 (otherwise known as Generation Z) are in turn considered the most technology proficient generation, their skills giving them a competitive edge in the job market. These people accept diversity and are diverse as a generation; their focus being on immediacy, they find it difficult to accept a mundane and time-consuming process of constructing a career; they perceive their work and family as one larger whole and like to work online; they are self-confident, risk takers and fast decision-makers (cf Żarczyńska-Dobiesz, Chomątowska B., 2014, p.408); they are now enter the job market, which offers fewer opportunities for stable employment than previously. Young people are constantly faced with the fact that a "blurred" market reality challenges the algorithms for lifetime professional choices and stable employment described as a linear temporal structure across the lifespan. A changing market reality requires that a profession is no longer considered a permanent category describing professional identities and the process of arranging a career based on life design (cf Savickas, 2005, 2009, 2011; Savickas et al,. 2009) and heuristics developed as individuals experience reality (Bańka, 2016, s.26) and using proactive strategies to construct a career, which may foster a sense of agency and influence on one's career across the life-span (Cybal-Michalska, 2013; Bańka, 2016).

Constructing a career is a long-term process that requires an active and controlled involvement in developing cognitive representations of the job market and a coping ability when faced with the challenges and difficulties of the marketplace. This means that individuals must be able to absorb the important themes of a career discourse that is present in society; scrutinise the world of work; analyse the market reality, including its components (areas of professional activity, jobs), their dynamics and the rules that govern the whole; separate the impact of marketing, media, and fashion from real social processes; and take into account the risk of failure and mistakes which they have to actively face.

Youthful impressions on a career, or how middle school students perceive and describe a professional career

Both popular knowledge and science, as well as individual beliefs, determine the individual awareness ${ }^{3}$ of career opportunities in the contemporary labour market.

\footnotetext{
${ }^{3}$ My definition of awareness was developed based on the reflections from the following publications: A. R. Damasio, Tajemnica świadomości. Jak ciało i emocje współtworza świadomość, Rebis. Dom Wydawniczy, Poznań 2000; J. Bobryk, Świadomość człowieka w epoce mediów elektronicznych, Polskie Towarzystwo Semiotyczne, Warszawa 2004; P. G. Zimbardo, R.L. Johnson, V. McCann, Psychologia. Kluczowe koncepcje, Vol.3 Struktura i funkcje świadomości, Wydawnictwo Naukowe PWN, Warszawa 2010;
} 
This produces internal and mental representations of this particular section of reality. Additionally, the awareness of career opportunities implies that individuals realise the knowledge and beliefs they have and are capable of developing a narrative (interpreting their own information, as well as selecting, arranging in order, describing, and analysing the information) on this particular section of social reality. Simultaneously, having a particular degree of self-awareness and self-esteem developed through social interaction, individuals can confront them with their awareness of the market reality to build plans, make choices, and take particular career-oriented decisions.

What career narratives do middle school students construct? What are the levels of career awareness among fifteen- or sixteen-year-olds, that is, people at the early stages of adolescence who are potentially able to rationally scrutinise the market reality and anticipate themselves in their future professional roles? What exemplifications of a successful career do they provide? What traits / phenomena / conditions do they identify that may either foster or hamper their careers? What career do they anticipate for themselves? These questions were included in a questionnaire survey of my own design?

The findings were verified with a questionnaire of my design called Kariera w ponowoczesnej rzeczywistości [Career in a Post-modern Reality]. The questionnaire comprised open-ended questions exclusively, which allowed the participants to answer more freely. Particular questions and general instructions were aimed at arranging the content of the answers provided by the participants in order.

The study involved a group of 179 randomly selected middle school students (third-graders, fifteen- or sixteen-year-olds) from several state-owned middle schools in Poznan. The gender distribution in the group was as follows: 55.87\% girls and $44,13 \%$ boys. Since the group is not representative enough, the outcomes may not be considered applicable to the entire population of young people in early adolescence. The outcomes are only intended as a signal of some of the phenomena occurring in the study group.

The considerations presented in the following sections of the paper were developed as part of the preliminary qualitative analysis of the study material.

Middle school students were asked to describe a career domain and provide the associations they have about it in their minds. Their contributions were limited in length, curt replies mixed with those that ran to several sentences long.

Middle school students used the word career as a value judgement, the way it is used in their vernacular. The term implies several different value judgements, most of them positive but including also ambivalent and negative ones. 
They rarely used the word to describe a professional journey. The following remarks:... A profession in which we specialise in... and .... In my opinion, career is like experience we gain across the life-span are rather rare.

Middle school students do not consider a career to be a goal in itself. Rather, it is a means to an end, that is, to produce a desirable state of affairs.

Middle school students associate the word career with a general idea of success and promotion.

... Career is like climbing up a ladder...

... Career, I don't know how to call it..., it's a journey to something unusual, a way to achieve something awesome...

... Career is when you celebrate success in a given area through your hard work...

Some of the respondents tend to link career as a visible progress, best reflected in promotion at work, with personality traits such as industry, commitment, and individual interests.

... I understand career as a journey to the profession of my choice. Climbing a career ladder is like a hard-working effort of extend one's opportunities and winning a promotion...

...For me, career means professional success. A job that you do because you choose it without any external pressure. For me, career is a profession I would like to pursue or a job I am good and successful at...

A large group of middle school students consider a career to be a property inherent in individuals who work to achieve their life goals and an element of personal development.

...For me, career is like a journey to achieve fulfilment in a profession of my dreams or doing something interesting in a daily basis. Fulfilling one's ambitions...

...Career brings the following to mind: a profession, education, work, commitment, ambition, pride, fulfilment...

...For me (...) career is something more than just a particular position or particular profession. This is a means to an end...

... Career is a way to gain or improve one's skills in areas suited to one's interests. Career means developing one's passions and striving for perfection, which is a way to achieve fulfilment...

... Career involves developing one's knowledge and learning things that go beyond the everyday. Career means doing things your way and doing things you like...

Some other mentioned the objective aspects of a career, including attributes such as media visibility, fame, material gratification. These narratives were dominated by the following statements: 
... Career means fame..., with a career, you are famous, not always popular, and most often loaded with money...

.... A high level of professional achievement which makes you famous...

...Career means that you are easily recognised because of your activity. People know who this person is and they like what he or she does...

... a job, a way to success, and consequently more money (better life)...

... You make a career if you become a manager in a company over a brief period of time... career means ... cash, some place to live, constant partying for the money you make...

... Career as a means to an end such as money or fame...

Some of the respondents verbalised their concerns about career prospects by pointing out some of the threats and costs involved in the process:

...Career means getting a better education. A person devoted to their work without any life of their own...

... Career is a poison that blinds people; one of the reasons why the human becomes a monster... (female)

...Career means stress, money, hard work, absence of sleep... (female)

In general, however, the vast majority of the respondents, even if they saw some of the drawbacks to "making a career", they considered it a desirable state of affairs that brings different individual profits (differently defined). With a career, one may achieve something, which is either a hazily defined success or goal, a promotion at work, particular material goods, fame and popularity, and inner fulfilment.

The respondents found little difficulty in personalising their careers or providing particular figures who would exemplify such a career. They mainly referred to famous people, who are recognised by various groups in society and whose life or affairs are widely publicised in the media or on the Internet: media-related professions (singers, musicians, actors, TV presenters, bloggers, etc.) and a broadly defined category of celebrities. According to most of the teenage respondents, a successful career may be mandated by media visibility and presence in a variety of popular culture contexts. The figures from the media also included people with real achievements in other areas, mainly successful athletes and politicians (!). Only rarely, the respondents mentioned persons from their closest social circles, e.g. family members or favourite teachers. Popular culture and the media set the trends that create particular fashions, promote fast-changing lifestyles, and influence the perceptions of professional career and success among young people. The respondents seemed to adhere to a narrative whereby only successful people make to the media and achieve recognition. They did so even if they addressed in the 
preceding passages some of the developmental aspects related to their career development.

Surprisingly, in multiple cases the students referred to factors, conditions, or phenomena that foster one's career as against some other that only hamper it. Admittedly, the students agreed that education (especially university degrees), foreign language proficiency, computer literacy, powerful drive, particular personal traits, or various talents may foster a successful career. However, they also pointed out that factors such as contacts, cronies, family support, lack of addictions, savvy, or no children may also facilitate a career. The respondents seemed to embrace an omnipresent cultural discourse on work and professional career which lays emphasis on social support, ambition and energy, resourcefulness, imagination (savvy, as indicated in their answers), and children or family (as time- and energy-intensive, while the time and energy could have been used for professional purposes).

Among the multiple factors that hamper one's career featured the antonyms of some of the expressions provided above, as well as poor commitment, poor professional self concept, or even laziness. Strikingly, this particular theme seemed to be overrepresented in the sample, many statements focusing on some of the aspects of physical appearance that can only hamper one's career (poor personal hygiene, tattoos, piercing, being fat and ugly, inappropriate appearance, poor looks). Considering the fact that most of the successful people mentioned by the respondents came from the media, the life of contemporary middle students being largely limited to virtual images, the importance of looks and appearance for future career prospects is of little or no surprise.

Questions on the plans and designs for personalised careers evinced three types of responses. Some of the middle school students who believed that a career is tantamount to professional success refused to make one due to a heavy toll on their personal lives. Some of the respondents mentioned particular professional areas or jobs and their imagined professional roles, but they did so very generally and only sparingly. In multiple cases, the questions in the survey appeared to prompt them to share a reflection, which had never been developed before. A relatively large group of secondary school students admitted to having no professional plans at all, without providing any potential professional interests, needs, or values, which subsequent specifications or descriptions address. The following passages are a suitable reflection of the intentions expressed by the teenage respondents, whose time perspective is primarily a present one and who are reluctant to reflect on their own future prospects.

... I have no idea what I would like to do, I have a myriad of ideas and none at all... I'll get myself a cosy blanket and warm apple pie and everything's going to be all right... 
... I don't have one journey to follow nor a detailed plan. Unfortunately, I don't even know which middle school I'm going to choose...

... I'm going to make a career, but I don't know which profession to choose ...

... I'm yet to decide what I'm going to do after secondary school...

...I'm yet to find my way in life...

Apparently, middle school students, who are still in for several years of education before they enter the job market, focus on the present time perspective. They are so engrossed in exploring their identities and answering the identity-related question who am I? (here and now) in the course of everyday experience that only few of them prove to be capable of a deeper reflection on the future. Admittedly, they are at the very beginning of creating their cognitive professional map that is based on the unique Self criterion (Gottfredson). The stage they are exploring is more of a probabilistic rather than implicative reflection (Dumora). The chaotic and fast-changing job market reality does not help young people to grow up with a view to entering the labour market and constructing their prospective career plans.

\section{References}

Bańka A. (2011). Pomoc psychologiczna wobec potrzeb rozwojowych jednostek i wyzwań współczesności [in:] M. Piorunek (ed.): Poradnictwo. Kolejne przybliżenia, Wydawnictwo Adam Marszałek, Toruń.

Bańka A. (2016). Proaktywność i decyzyjność. Nowe miary adaptacji twórczej do rozmytej rzeczywistości rynku pracy, [in:] V. Drabik-Podgórna, M. Podgórny (eds.): Zawód czy kompetencje? Wymagania rynku pracy a wspieranie rozwoju kariery, Wydawnictwo Adam Marszałek, Toruń.

Bobryk J. (2004). Świadomość człowieka w epoce mediów elektronicznych, Polskie Towarzystwo Semiotyczne, Warszawa.

Boudon R. (2008). Efekt odwrócenia, Oficyna Naukowa, Warszawa.

Cybal-Michalska A. (2013). Młodzież akademicka a kariera zawodowa, Oficyna Wydawnicza "Impuls", Kraków.

Damasio A. R.(2000). Tajemnica świadomości. Jak ciało i emocje współtworza świadomość, Rebis. Dom Wydawniczy, Poznań.

Długosz P. (2013). Efekt odwrócenia - przypadek polskiego systemu edukacji, „Teraźniejszość - Człowiek - Edukacja”, 3 (63).

Druckner P.F. (2008). The age of discontinuity, Transaction Publisher, New Brunswick.

Dumora, B. (1990). La dynamiqe vocationelle chez l'adolescent de college: continuite etrupture, „L'Orientation scolaire et professionnelle”, $\mathrm{nr} 19$.

Erikson E. H (1968). Identity youth and crisis, W.W.Norton\&Company, New York.

Erikson, E.H (1989). Identitaet und Lebenszyklus, Shurkamp Taschenbuch Verlag, Frankfurt am Mein.

Giddens, A. (2007). Nowoczesność $i$ tożsamość. „Ja” i społeczeństwo w epoce późnej nowoczesności, Wydawnictwo Naukowe PWN, Warszawa. 
Gottfredson L. (1996). Gottfredson's Theory of Circumscription and Compromise/w/ Brown D.,Brooks L. (eds.) Carrer Choice and Development, San Francisco.

Guichard J.,Huteau M. (2005). Psychologia orientacji i poradnictwa zawodowego, Impuls, Kraków.

Kubacka-Jasiewicz D., Passowicz P. (2014). Dorastanie we współczesności. Postawy, wartości i doświadczanie czasu a kryzysy rozwoju pokolenia po transformacji, „Czasopismo Psychologiczne”, $20,2$.

Marcia J.E., Waterman A.S., Matteson D. R., Archer S.L., Orlofsky J.L. (1993). Ego Identity. A Handbook for Psychosocial Research, Springer-Verlag, New York.

Modrzewski, J. (2004). Socjalizacja i uczestnictwo społeczne. Studium socjopedagogiczne, Wydawnictwo Naukowe UAM, Poznań.

Osipow, S.H. (1973).Theories of career development, Prentice-Hall, Englewood C., New Jersey.

Piorunek M. (2004), Projektowanie przyszłości edukacyjno-zawodowej w okresie adolescencji, Wydawnictwo Naukowe UAM, Poznań.

Piorunek M. (2006). The Youth as the Clients of Career Guidance: Selected Studies of Polish Adolescents /in/ "The New Educational Review" 2.

Piorunek M. (2007). L'elaboration des projets a l'adolescence: etude empirique aupres d'adolescents polonaise, "Lorientation scolaire et professionnelle" 2.

Piorunek M. (2011). (Bez)sens planowania przyszłości... Refleksje o adolescencyjnym projektowaniu przyszłości edukacyjno-zawodowej, "Studia Edukacyjne”, 18.

Savickas M. L., (2005 ). Life-Long Self-Construction, "International Journal for Educational and Vocational Guidance", 5.

Savickas M. L.. (2009) Career studies as self-making and life designing, "Career Research \& Development", 24.

Savickas M. L., (2011). Constructing Careers: Actor, Agent and Author, "Journal of Employment Counselling", 48.

Savickas M. L., Nota L., Rossier J., Dauwalder J-P., Duarte M. E., Guichard J., Soresi S., Van Esbroeck R., (2009). Life designing: A paradigm for career construction in the 21st century, "Journal of Vocational Behavior", 75/3.

Smart, R. , Peterson, C. (1997). Super's career stages and the decision to change careers, "Journal of Vocational Behavior", 51.

Super D.E., Savickas M.L., Super C.M. (1996). The life-Span, life-Space approach to career (in) D. Brown, L. Brooks e\& Associates (eds.), Career Choice and Development, Jossey-Bass, San Francisco.

Super, D.E. (1990). A life- span, life-space approach to career development. [in:] W D. Brown \& L.Brooks (eds.), Career choice and development: Applying contemporary theories to practice, CA: Jossey-Bass, San Francisco.

Szafraniec K. (2011), Młodzi 2011, Kancelaria Prezesa Rady Ministrów, Warszawa.

Wrzesień W. (2007). Czy pokoleniowość nam się nie przydarzy? Kilka uwag o wspótczesnej polskiej młodzieży, "Nauka", 3.

Zimbardo P. G., Johnson R. L., McCann V. (2010). Psychologia. Kluczowe koncepcje, Vol. 3 Struktura i funkcje świadomości, Wydawnictwo Naukowe PWN, Warszawa.

Żarczyńska-Dobiesz A., Chomątowska B. (2014). Pokolenie "Z” na rynku pracy - wyzwania dla zarządzania zasobami ludzkimi, "Prace Naukowe Uniwersytetu Ekonomicznego we Wrocławiu", 350. 